\title{
PENETAPAN KADAR PEMANIS BUATAN (Na-SIKLAMAT) PADA BEBERAPA MINUMAN SERBUK INSTAN DI KOTA SURAKARTA
}

\author{
Determination Of Artificial Sweetener Levels (Na-Cyclamat) \\ On Some Instant Powder Drinks In Surakarta \\ Meliana Novitasari ${ }^{1}$, Nova Rahma ${ }^{2}$, Kiki Puspitasary ${ }^{3}$ \\ STIKES Mamba'ul 'Ulum Surakarta \\ (meliananovitasari@yahoo.co.id)
}

\begin{abstract}
ABSTRAK
Latar Belakang : Bahan kimia merupakan sesuatu yang tak pernah lepas dari kehidupan sehari-hari yang sebagai bahan tambahan pada makanan dan minuman. Bahan tambahan merupakan bahan yang sengaja ditambahkan kedalam makanan dan minuman untuk mendapatkan kualitas yang lebih baik.

Tujuan : Untuk mengetahui kadar pemanis buatan Na-siklamat yang terdapat dalam beberapa minuman serbuk instan.

Metode : Rancangan penelitian yang digunakan dalam penelitian ini adalah penelitian eksperimen laboratorium.

Hasil : Penetapan kadar pemanis buatan (Na-siklamat) pada beberapa minuman serbuk instan dikota Surakarta. Penelitian ini bertujuan untuk mengetahui berapa kadar pemanis buatan Na-siklamat dengan metode alkalimetri yang meliputi : Uji kualitatif yang dapat mengidentifikasi Natrium siklamat dalam sampel dengan menggunakan $\mathrm{BaCl}_{2}, \mathrm{HCl}$ pekat dan $\mathrm{NaNO}_{2} 10 \%$ akan terjadi endapan yang menunjukan adanya siklamat, uji kuantitatif yang dapat menetapkan kadar pada tiap sampel dilakukan titrasi dengan larutan $\mathrm{NaOH} 0,1 \mathrm{~N}$ dan akan terjadi perubahan warna pada masing-masing sampel.

Simpulan : Hasil penelitian menunjukan bahwa pada 3 sampel minuman serbuk instan dengan merek berbeda yang di ambil di Kota Surakarta, semuanya mengandung Natrium siklamat dengan kadar Sampel A 0,058\% atau 0,0058 gram, Sampel B 0,052\% atau 0,0052 gram dan Sampel C 1,03\% atau 0,0103 gram. Dari hasil yang diperoleh kadar yang paling tinggi Natrium siklamatnya ialah Sampel $\mathrm{C}$, yang dimana dari ketiga sampel tersebut masih memenuhi syarat kadar yang sudah

ditetapkan dalam peraturan Mentri Kesehatan RI.
\end{abstract}

Kata kunci : Penetapan Kadar, Natrium Siklamat, Minuman Serbuk.

\section{ABSTRACT}

Background: Chemicals are something that can never be separated from everyday life as an additional ingredient in food and drinks. Additional ingredients are ingredients that are deliberately added to food and drinks to get better quality. 
The Purpose: To determine the levels of artificial sweetener Na-cyclamate contained in some instant powder drinks.

Method: The research design used in this study was laboratory experimental research.

Result : Determination of levels of artificial sweeteners (Na-cyclamate) in some instant powder drinks in the city of Surakarta. This study aims to find out what levels of artificial sweetener Na-cyclamate with alkalimetry methods include: Qualitative tests that can identify cyclamate Sodium in the sample using BaCl2, concentrated $\mathrm{HCl}$ and $\mathrm{NaNO} 210 \%$ will occur sediment that indicates the presence of cyclamate, quantitative tests that can determine levels in each sample were titrated with $0.1 \mathrm{~N} \mathrm{NaOH}$ solution and there would be a change in color in each sample.

Conclusion: The results showed that in 3 samples of instant powder drinks with different brands taken in the city of Surakarta, all of them contained Sodium cyclamate with levels of Sample A $0.058 \%$ or 0.0058 gram, Sample B 0.052\% or 0.0052 gram and Sample C 1,03\% or 0.0103 grams. From the results obtained, the highest level of sodium cyclamate is Sample $C$, which of the three samples still meets the level requirements set in the Indonesian Minister of Health regulations.

Key words: Determination of Levels, Sodium Cyclamate, Powder Drinks

\section{PENDAHULUAN}

Bahan kimia merupakan sesuatu yang tak pernah lepas dari kehidupan seharihari yang sebagai bahan tambahan pada makanan dan minuman. Bahan tambahan merupakan bahan yang sengaja ditambahkan kedalam makanan dan minuman untuk mendapatkan kualitas yang lebih baik. Bahan tambahan yang dikenal dengan zat adiktif pada makanan dan minuman dapat berupa pewarna, penyedap rasa, aroma, pemantap, antioksidan, pengawet, pengemulsi, pemucat, pengental, dan pemanis (Handayani dkk., 2015).

Di Indonesia penggunaan bahan tambahan pemanis diatur dengan peraturan Mentri Kesehatan Republik Indonesia Nomor 722/Menkes/ Per/IX/1988. Dimana, pemanis adalah bahan tambahan pangan yang dapat menyebabkan rasa manis pada pangan, yang hampir atau tidak mempunyai nilai gizi (Handayani dkk., 2015).

Pemanis merupakan senyawa kimia yang sering ditambahkan dan digunakan untuk keperluan produk olahan pangan, industri serta minuman dan makanan kesehatan. Pemanis berfungsi untuk meningkatkan cita rasa dan aroma, memperbaiki sifat-sifat fisik. Tujuan pemanis sebagai pengawet adalah memperbaiki sifat-sifat kimia sekaligus merupakan sumber kalori (Julaeha dkk., 2016).

Pemanis buatan yang banyak beredar dimasyarakat adalah siklamat. Konsumsi siklamat yang melebihi dosis akan mengakibatkan kanker kandung kemih. Selain itu akan menyebabkan tumor paru, hati dan limfa. Produsen lebih sering menggunakan pemanis buatan karena harga relatif murah dan rasa manis yang dihasilkan 30 kali lebih manis dari pada sukrosa (gula putih) (Nurlailah dkk., 
2017). Menurut Menkes kadar maksimum penggunaan siklamat untuk jenis pangan dan minuman adalah $3 \mathrm{~g} / \mathrm{kg}$ berat badan (Handayani dkk., 2015).

Nama lain dari siklamat adalah Natrium sikloheksisulfat atau Natrium siklmat dengan nama dagang antara lain: assugrin, suracyl, atau sucrose. Siklamat bersifat mudah larut dalam air dan tahan terhadap panas. Di Indonesia pemakaian siklamat sering disalah gunakan dan penggunaannya melebihi batas yang di ijinkan (Handayani dkk., 2015).

Terdapat beberapa jenis pemanis buatan yang sering digunakan untuk produk olahan pangan khususnya minuman diantaranya sakarin, aspartam dan siklamat. Peneliti tertarik dengan pemanis buatan siklamat atau Na- siklamat karena banyak digunakan dalam produk pangan olahan minuman yang rasanya lebih manis dari sukrosa, dalam pemanis buatan sakarin dan aspartam rasa manis yang dihasilkan terdapat rasa pahit. Batas maksimum sakarin 500_mg/kg, aspartam $50 \mathrm{mg} / \mathrm{kg}$, dan siklamat $3 \mathrm{~g} / \mathrm{kg}$. Dosis yang melebihi batas maksimum dari beberapa jenis pemanis dapat menyebabkan gangguan kesehatan. Sampel yang digunakan dalam beberapa minuman serbuk instan dalam penelitian ini terdapat pamanis buatan Na-siklamat, dimana minuman serbuk instan harganya relatif murah, warnanya menarik perhatian dan rasanya sangat enak yang dijual ditempat yang mudah dijangkau seperti dikantin sekolah, supermarket dan tempat jajanan lainnya, sehingga banyak kita jumpai dari anak-anak hingga dewasa mengonsumsi minuman serbuk tersebut bahkan tanpa dicampurkan air karena lebih enak rasanya tanpa dicampurkan air.

Dalam penelitian ini digunakan metode Alkalimetri untuk mengetahui kadar pemanis buatan yang terdapat dalam sampel yang bereaksi menetralkan reaksi antara ion hidrogen dengan ion hidroksida untuk menghasilkan larutan yang bersifat netral.

\section{METODE PENELITIAN}

Rancangans penelitian yang digunakan dalam penelitian ini adalah penelitian eksperimen laboratorium. Variabel ini menggunakan variabel bebas yaitu minuman serbuk instan yang memiliki pemanis buatan Natrium siklamat. Menkonsumsi siklamat yang melebihi dosis akan mengakibatkan kanker kandung kemih. Selain itu akan menyebabkaan tumor paru, hati dan limfa. Variabel terikat yang digunakan adalah sifat dari sediaan pemanis buatan yang di gunakan pada salah satu produk minuman siap saji yang banyak mengandung pemanis buatan. Pemanis buatan yang sering digunakan adalah Natrium siklamat. Penggunaan Nasiklamat dalam dosis besar akan menimbulkan gangguan kesehatan.

Populasi sekaligus sampel dari penelitian ini yaitu siklamat yang biasanya digunakan dalam bentuk garam seperti natrium siklamat atau kalsium siklamat. Sedangkan sakarin merupakan senyawa kimia yang sering ditambahkan dan digunakan untuk keperluan produk olahan pangan, industri serta minuman dan makanan, kemudian yang terakhir yaitu aspartam yang biasanya juga digunakan sebagai pemanis dalam berbagai makanan dan minuman. Setelah dikonsumsi, aspartam akan dimetabolisme menjadi tiga senyawa utama yaitu asam aspartat, fenilalanin dan metanol yang secara alami juga terdapat pada makanan lain dan dalam tubuh manusia 


\section{HASIL DAN PEMBAHASAN}

a. Hasil Uji Kualitatif

Tabel.1. Identifikasi Natrium siklamat pada minuman serbuk instan

\begin{tabular}{ccc}
\hline No & Sampel & Hasil \\
\hline 1. & Sampel A & Positif (+) \\
2. & Sampel B & Positif (+) \\
3. & Sampel C & Positif (+)
\end{tabular}

Keterangan $:(+)=$ menunjukan adanya Natrium siklamat pada masingmasing sampel

b. Hasil Uji Kuantitatif

Tabel.2. Penetapan kadar Natrium siklamat pada minuman serbuk instan

\begin{tabular}{ccccc}
\hline Sampel & Replikasi & Volume & Warna & Kadar (\%) \\
& & & & \\
Sampel & I & 8,0 & Merah muda & \\
A & II & 14,0 & Merah muda & \\
& I & 23,7 & Merah muda & $0,58 \%$ \\
Sampel & II & 7,2 & Coklat muda & \\
B & III & 24 & Coklat muda & \\
& I & 5,0 & Coklat muda & $0,52 \%$ \\
Sampel & II & 12,0 & Ungu pekat & \\
C & III & 18.5 & Ungu pekat & \\
\hline
\end{tabular}

Keterangan : Sampel A = Direplikasi sebanyak 3 kali untuk menetapkan kadar Na-siklamat, dan menghasilkan titik akhir titrasi berwarna merah muda

Sampel B = Direplikasi sebanyak 3 kali untuk menetapkan kadar Na-siklamat, dan menghasilkan titik akhir titrasi berwarna coklat muda

Sampel C = Direplikasi sebanyak 3 kali untuk menetapkan kadar Na-siklamat, dan menghasilkan titk akhir tittrasi berwarna ungu pekat

Dalam kehidupan sehari-hari penggunaan bahan kimia sebagai bahan tambahan pangan pada makanan dan minuman sering ditemui. Bahan tambahan pangan merupakan bahan yang sengaja ditambahkan pada makanan dan minuman untuk mendapatkan kualitas yang lebih baik, biasanya bahan tambahan pada makanan dan minuman berupa pewarna, penyedap rasa, aroma, antioksidan, pengemulsi, pengental dan pemanis. Pemanis merupakan senyawa kimia yang sering ditambahkan pada olahan makanan dan minuman, guna untuk meningkatkan cita rasa dan aroma serta memperbaiki sifat- 
sifat fisik. Pemanis yang digunakan dalam produk minuman biasanya menggunakan pemanis buatan yang memberikan rasa manis tetapi tidak memiliki nilai gizi. Sebagai contoh pemanis yang sering digunakan pada produk olahan minuman ialah sakarin, aspartam dan siklamat.

Pemanis buatan tersebut memiliki kemanisan yang berbeda-beda, adapun pemanis buatan yang dianjurkan dalam peraturan Mentri kesehatan ialah sakarin $500 \mathrm{mg} / \mathrm{kg}$, aspartam $40 \mathrm{mg} / \mathrm{kg}$ dan siklamat $3 \mathrm{~g} / \mathrm{kg}$. Pada penelitian ini pemanis buatan yang akan diteliti ialah siklamat karena siklamat sering digunakan pada produk olahan minuman yang harganya relatif murah dan rasanya lebih manis dari sukrosa, berbeda dengan sakarin dan aspartam rasa manis yang dihasilkan terdapat rasa pahit.

Natrium siklamat merupakan pemanis yang dibiasanya ditambahkan pada makanan dan minuman yang memiliki tingkat kemanisan 30-40kali lebih manis dari sukrosa.

Sampel yang digunakan pada penelitian ini ialah sampel minuman serbuk instan yang berada di kota Surakarta yang berjumlah 3 dengan merek berbeda. Tiap sampel diberi label sampel A, B dan C. Sampel minuman serbuk dilakukan uji kualitatif yang dapat mengidentifikasi adanya siklamat dalam tiap sampel, dengan cara tiap sampel dilarutkan dengan aquades hingga $100 \mathrm{ml}$ kemudian direaksikan dengan $\mathrm{BaCl}_{2}$ kemudian ditambahkan $10,0 \mathrm{ml} \mathrm{HCl}$ pekat dan $10,0 \mathrm{ml} \mathrm{NaNO} \mathrm{Na}_{2} 10 \%$ dipanasakan diatas penangas air hingga mendidih kemudian didiamkan sampai terjadi endapan yang menunjukan adanya siklamat. Pada peneltian ini hasil yang didapat dari sampel A, B dan $\mathrm{C}$ positif mengandung siklamat yang terdapat endapan yang menunjukan adanya siklamat.

Pada uji kuantitatif sampel minuman serbuk A, B dan C dilakukan untuk mengetahui berapa banyak kadar yang terdapat dalam tiap sampel tersebut dengan cara 8,0 gram sampel dilarutkan dengan aquades hingga $100 \mathrm{ml}$ kemudian diambil $25 \mathrm{ml}$ larutan sampel masukkan kedalam erlenmeyer kemudian ditambahkan 2-3 tetes indikator $\mathrm{pp} /$ Fenolftalein, kemudian dititrasi dengan larutan $\mathrm{NaOH} 0,1 \mathrm{~N}$ untuk menetapkan kadar Natrium siklamat pada minuman serbuk instan yang dilakukan sebanyak 3 kali. Hasil titrasi pada sampel A dari orange berubah menjadi merah muda, sampel B dari warna orange berubah menjadi coklat muda, dan sampel $\mathrm{C}$ dari warna coklat berubah menjadi warna ungu pekat. Kadar $\%$ siklamat dari sampel A $0,58 \%$ atau 0,0058 gram, sampel B $0,52 \%$ atau 0,0052 gram dan Sampel C 1,03\% atau 0,0103 gram. Kadar maksimum penggunaan siklamat menurut peraturan Mentri Kesehatan untuk jenis pangan dan minuman ialah $3 \mathrm{gr} / \mathrm{kg}$ berat bahan. Dapat disimpulkan harga ambang batas siklamat ialah 3 g dalam $1 \mathrm{~kg}$ minuman, jadi dalam 1 gram minuman serbuk instan harga ambang batas penggunaan siklamat adalah 0,003 gram dan 8 gram minuman serbuk instan yang digunakan dalam peneltian ini harga ambang batas penggunaan siklamat ialah 0,024 gram. Dari hasil diatas dapat disimpulkan yang lebih tinggi kadar pemanis buatan Natrium siklamat ialah sampel $C$ dan ketiga sampel tersebut masih memenuhi harga ambang batas kadar Natrium siklamat yang di izinkan.

Hasil ini didukung oleh teori yang menyatakan adanya suatu siklamat ditandai dengan terjadinya endapan putih pada tiap sampel. Perubahan warna 
yang terjadi pada titik akhir titrasi sampel A sesuai dengan teori yang dimana warna awal dari larutan sampel berwarna orange berubah menjadi warna merah muda, sampel B warna awal dari larutan sampel berwarna orange berubah menjadi warna coklat muda dan sampel $\mathrm{C}$ warna awal dari larutan sampel berwarna coklat berubah menjadi warna ungu pekat. Pada penelitian sebelumnya hasil yang didapatkan dari sampel minuman serbuk instan dengan merek berbeda ialah ada yang melebihi kadar dan adapula yang memenuhi kadar menurut Peraturan Mentri Kesehatan.

Berdasarkan hasil di atas penggunaan siklamat yang berlebihan dapat menyebabkan gangguan kesehatan, dari gangguan kesehatan jangka pendek hingga jangka panjang yang dimana jangka pendeknya akan menimbulkan sakit perut, sakit kepala, diare, demam, mual, muntah, alergi, insomnia, kebingungan, kebotakan, dan sesak nafas (asma), sedangkan jangka panjang yang akan menimbulkan timbulnya kanker atau karsionogenik, gangguan saraf, gangguan fungsi hati, iritasi lambung, perubahan fungsi sel dan kanker otak.

\section{SIMPULAN DAN SARAN}

\section{Simpulan}

Berdasarkan pemeriksaan uji kuantitatif pada minuman serbuk instan yang dilakukan untuk mengetahui kadar pemanis buatan Natrium siklamat yang berada di kota Surakarta yang di dapat pada sampel A 0,58\% atau 0,0058 gram, sampel B $0,52 \%$ atau 0,0052 gram dan sampel $\mathrm{C} 1,03 \%$ atau 0,0103 gram, yang mana dari ketiga sampel tersebut kadar Natrium siklamat pada beberapa minuman serbuk instan masih memenuhi harga ambang batas kadar Natrium siklamat yang sudah ditetapkan pada peraturan Mentri Kesehatan dan kadar yang paling tinggi dari ketiga sampel diatas ialah sampel C.

\section{Saran}

Adapun saran saya pada penelitian ini adalah: Menghimbau kepada masyarakat untuk mengecek kadar pemanis buatan dengan melihat komposisi pemanis buatan (Natrium siklamat) terlebih dahulu sebelum dikonsumsi. Menghimbau kepada BPOM untuk melakukan pemeriksaan secara kontinyu dalam produk olahan makanan dan minuman yang sudah kadarluasa dan tidak memiliki izin bagi produsen yang melebihkan kadar pemanis buatan natirum siklamat. Menghimbau kepada peneliti selanjutnya agar menambahkan beberapa sampel jika melakukan penelitian tentang pemanis buatan Natrium siklamat.

\section{DAFTAR PUSTAKA}

Andriyani, 2014. Pengaruh Minuman Kemasan Sachet (M) dengan Frekuensi Berbeda Terhadap Kadar Kolestrol Darah Mencit (Mus musculus). Surakarta: Universitas Muhammadiyah Surakarta

Ariya W P, Darmawati, Mocthtar, 2016. Simultaneous Determination Of Sodium Benzoate and Sodium Cylamate In Soft Drink Using High 
Performane Liquid Chromatography. Surabaya: Universitas Airlangga

Dijen POM, 1979. Farmakope Indonesia Edisi III. Jakarta: Departemen Kesehatan RI

Dirjen POM, 1995. Farmakope Indonesia Edisi IV. Jakarta: Departemen Kesehatan RI

Dirjen POM, 2014. Farmakope Indonesia Edisi V. Jakarta: Departemen Kesehatan RI

Egi A S, Moh Nuh I, Wahab, 2016. Analisis Kandungan Zat Pemanis Sakarin dan Siklamat pada Minuman yang di Perdagangkan diSekolah Dasar diKelurahan Wua-wua Kota Kendari. Kendari: Universitas Halu Oleo

Fatimah, Arisandi, Yunanto, 2015. Penetapan Kadar Sakarin Minuman Ringan Gelas Plastik yang dijual di Pasar Beringharjo, Yogyakarta. Yogyakarta: STIKES Guna Bangsa

Gandjar IG, Rahman, 2015. Kimia Farmasi Analisis. Yogyakarta: Celaban Timur UH

Handayani T, Agustina A, 2015. Penetapan Kadar Pemanis Buatan (NaSiklamat) pada Minuman Serbuk Instan dengan Metode Alkalimetri. Klaten: Stikes Muhammadiyah Klaten

Handayani, T., \& Agustina, A. (2015). Penetapan Kadar Pemanis Buatan (Na-

Siklamat) Pada Minuman Serbuk Instan Dengan Metode

Alkalimetri. Jurnal Farmasi Sains dan Praktis, 1(1), 1-6.

Julaeha, Nurhayati Ai, Mahmudatassa'adah Ai, 2016. Penerapan Pengetahuan Bahan Tambahan Pangan pada pemilihan Makanan Jajanan Mahasiswa Pendidikan Tata Boga Upi. Bandung: Universitas Pendidikan Indonesia

Mairizki, 2014. Penentuan Natrium Sakarin, Asam benzoate, dan Kafein Menggunakan Kromatografi Cair Kinerja Tinggi Fasa Balik. Pekanbaru: Universitas Islam Riau

Mulyatmo, Hariyatmi, 2015. Pengaruh Konsumsi Minuman Instan dengan Frekuensi Berbeda Terhadap Kadar Ureum Darah Mencit (Mus Musculus). Surakarta:Universitas Muhammadiyah Surakarta

Nurlailah, Nurhayati A, Oktiyani, 2017. Analisis Kadar Siklamat padaa Es Krim di Kota Banjarbaru. Bajnarbaru: Poltekes Kemenkes Banjarmasin

Pertiwi, Suryani, 2017. Pengaruh Pemberian Minuman Berenergi ysng Mengandung Aspartam terhadap Nilai Fungsi Ginjal Tikus Jantan (Rattus norvegicus L). Sumatera Utara: Universitas Muhammadiyah Sumatera Utara

Effendi, S. Ranny, Y. Fardian, N. Maulina, F. 2016. Uji Kualitatif dan Kuantitatif Kandungan Pemanis Buatan Siklamat pada Selai Roti di Kota Lhokseumawe tahun 2016. Lhokseumawe: Universitas Malikussaleh

Yohana, 2016. Karakteristik Fisiko Kimia dan Organoleptik Minuman Serbuk Instan dari Campuran Sari Buah Pepino (Solanum Muricatum, Aiton) dan Sari Buah Terung Pirus (Cyphomandra Betacea, Sent). Padang: Universitas Andalas 